JOURNALISM SERIES. NO. 35

Robert S. Mann, Editor

\title{
Advertising and Publicity
}

Addresses Delivered at the Sixteenth Annual Journalism Week at the University of Missouri, May 4-8, 1925.

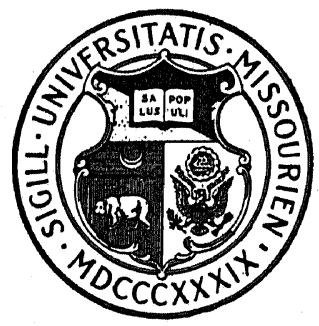




\section{Contents}

The addresses in this bulletin are only a few of the many excellent ones that filled the five-day program of the sixteenth annual Journalism Week at the School of Journalism of the University of Missouri. Other of the addresses are being published in a separate bulletin, No. 36, entitled "Fournalism Week, 1925." Copies may be obtained by addressing the dean of the School of Fournalism.

Journalism Week has become an institution at this school, attended yearly by writers, editors, artists, advertising workers, and others serving in almost all sorts of journalistic capacities. The Missouri Press Association and the Missouri Writers Guild met at the School of Journalism in connection with the exercises cach May. All persons interested in journalism are invited to attend. Announcements of future Journalism Weeks may be obtained by writing to the School of Journalism.

The addresses in this bulletin are as follor's:

Newspaper Organization and Somp Obshrovations on Newipaptir ADVERTISING

By George M. Burbach, Advertising Manager, St. Louis PostDispatch

Getring National Advertising ror thit Country Newspaper

By James O'Shaughnessy, Executive Secretary. American Association of Advertising Agencies Page 9

Building a Classifited Page in a Countroy Wiekri,

By W. Earle Dye, Editor, Richmond Missourian Page I3

Watching For Fake Advertising

By R. C. Ficrguson, Editor, Buffalo (Mo.) Reflex Page I7

Advertising From the Viewroint of the Country Mirchant

By John H. DeWild, Manager of the Merchants' Service Department, Ely \& Walker Dry Goods Co., St. Louis Page 2I

AdverTising a City

By G.V. Kenton, Editor, St. Louis News Service Page 25

The New Profession-Public Relations

By Frank LeRoy Blanchard, Director of Public Relations, Henry L. Doherty \& Company, New York 


\title{
Advertising and Publicity
}

\section{Nerespaper Organization and Some Observations on Newspaper Advertising}

\author{
By George M. Burbach \\ Advertising Manager, St. Louis Post-Dispatch
}

My twenty-five years in the newspaper business has found me associated with metropolitan newspapers; therefore I may not fully appreciate the trials and tribulations of the publisher in the small town. However, I believe, the newspapers in the semi-metropolitan towns can use to advantage the successful ideas of metropolitan newspapers as a basis for their organization.

The newspaper of today, whether large or small, must be an organization of aggressive, determined, clear-thinking men and women. Each department must be directed by and made up of the best talent available in their particular line, for the final result reflects the organization which makes it.

The organization should be divided in to three departments-Editorial, Circulation, and Advertising. One is just as essential to success as the other. Of course, the first and most essential department is the Editorial and News Department, which really makes the paper what it is. The Circulation Department sells the product through its established distribution channels, and the Advertising Department must make a profit out of the product which the other two departments produce.

Because of the element of time, and the possibility of issuing an extra any minute through the day, it is necessary to have a larger force and mechanical equipment on an afternoon newspaper than a morning paper. The afternoon newspaper is in reality in a race with the clock. Everything must be done promptly, accurately, and on fixed schedule. (No one department or individual can fall behind schedule, as a single delay anywhere along the line means late delivery and a consequent loss of circulation and prestige.)

The actual building and making-up of an afternoon newspaper commences long before most people are up for the day, when the first members of the editorial staff report for duty. From that time on it is a matter of each member of the entire organization doing his or her part to the best of his ability, and, under unusual pressure, assembling the great mass of information gathered from all parts of the world. As the clock ticks off minute after minute the tenseness becomes greater until the first edition is whirled through the great battery of octuple presses and in to the hands of a receptive public.

At this point it may be well for me to briefly sketch the organization of the average metropolitan newspaper. This, of course, is subject to considerable latitude, depending on the size of the city, the circulation, and the advertising volume.

The Editorial Department is divided into the following three general classifications-Editorial, News, and Features.

What the editorial page lacks in space allotment it more than makes up in its relative importance to the paper as a whole. It is frequently referred to as the backbone of the daily newspaper.

The daily cartoon, which has become a fixture on many editorial pages, is a summary of the most important event of the day visualized so everyone 
may understand it. Simplicity should be its principal characteristic. It may or may not be humorous. The editorial page may include a designated space and location for letters from readers who wish to express their views on topics of the day. Other appropriate features may be included on the page.

Some of the more important classifications in the local news department are Sport, Financial, Society, Art, Music, Drama, Literature and Books.

Telegraphic news is gathered from all corners of the civilized world through the reliable Associated Press service, and by special and exclusive New York and Washington correspondents with direct wires to our plant. Most metropolitan newspapers have an office and staff writers in the capitals of the state and the nation, and special news correspondents in all the principal centers of Continental Europe.

Features include Comics, Rotogravure, Daily Magazine, Sunday Magazine, Radio, Woman's Page, Questions and Answers, and general features obtainable from time to time.

The scope of the Production Department includes Photo-Engraving, Composing Room, Stereotyping Department, Press Room, Mail Room, and Radio Broadcasting.

The Composing Room is usually divided in to four separate units: one for handling news matter, one for display advertising, one for classified advertising, and one for make-up.

The Stereotyping Department and the Press Room handle the assembled load, which comes to them from the Composing Room and the Photo-Engraving Department. These departments must be equipped at all times to meet any emergency even if it requires an entire make-over of the newspaper.

Recently, the Post-Dispatch had a situation develop which made it necessary to make over forty pages of a sixty-four-page daily paper. This meant that the Stereotyping Department had to cast one plate for each of our eight presses for each of forty pages, or a total of 320 extra casts. Likewise, the Press Room had to remove the 320 discarded plates from the eight presses and replace them with the 320 new plates. All of this had to be done between editions within a total lapsed time of only ninety minutes-an average of almost four plates a minute.

The Mail Room is the real neck of the bottle, where the finished paper passes through-destined for all parts of the world. The very moment the first press starts you can hear the hum of motorcycles and the buzz of the delivery trucks adjoining the mail room. Motorcycles with side carts are used for quick delivery, sending a limited number of newspapers to the strategic distribution points to supply the dealers and newsboys in every part of the city with sufficient papers to meet an immediate demand. Rapid trucks quickly follow the routes of the motorcycles in order to supply the continued demand for each edition. In less than forty minutes af ter the first press starts we have papers in every part of St. Louis within a radius of fourteen miles from the Post-Dispatch plant. This process of delivery must be repeated from four to six times a day, depending on the number of editions, and on whether or not news of sufficient importance requires an extra.

Today the newspapers are competing with the United States mail service and have extended their delivery service with high-speed delivery trucks traveling almost one hundred miles from the home plant over paved highways -unfortunately, not in Missouri, as the roads will not permit. 
During the recent tornado in southern Illinois the Post-Dispatch delivered papers in Murphysboro by automobile trucks, containing early reports of the storm, before the full magnitude and horror of the disaster was realized by the people of that stricken section.

That same evening five news men and photographers were rushed in automobiles and by trains to various points in the devasted area to gather news and photographs. The next day before noon the Post-Dispatch printed a full page of pictures of the storm damage taken by flashlight the night before. Photographs were telegraphed direct from the Post-Dispatch's plant by the new Belin System to the New York World, which enabled the people of the great metropolis to realize the real damage that had been done, in less than twenty-four hours after it happened.

The Advertising Department of a metropolitan newspaper is divided into seven units: Local Advertising, National Advertising, Merchandising, Research, Promotion and Publicity, Classified, and Clerical. The Advertising Department is the cash register ringer, although the Circulation Department also produces a substantial volume of revenue.

In the last twenty-five years there has been a remarkable change in the methods employed in selling newspaper advertising. In the early days the question of circulation, results, service, and salesmanship did not come into play, as the good mixer and the greatest prevaricator usually got the business; but today the metropolitan newspaper staff consists of high-powered skillful salesmen, second to none when it comes to selling.

The local advertising salesman today must be neat, alert, have initiative, be resourceful and capable of offering worth-while suggestions to the advertiser regarding copy, merchandise, window display, store arrangement. $\mathrm{He}$ should also be qualified to talk golf, tennis, baseball, grand opera, and worldwide news events.

The training given you students of journalism, and the work you do at Columbia, will equip you with some of these requirements, but it will require close application and hard work and experience to develop you to a point where you are the success you hope to be; so don't become discouragedstick to it.

We strive to keep our salesmen fully informed regarding circulation of all newspapers in the field, rates, retail conditions and information about the market. Helpful sales meetings are held, special awards are made, contests employed to stimulate rivalry and to develop action and initiative.

One of the best producers of lineage is to supply the salesmen with carefully prepared copy for their advertisers. This is particularly true with newspapers in second and third position in the field, where service and suggestions take the place of circulation or results.

In these days of service organizations, you can buy splendid salesmanship talks and hints from firms in Chicago and New York, which makes a specialty of that 'wörk. Arrangements cän be made to have these letters reach your salesmen each week. If your organization is large enough have the letter read to the entire group, then discuss the various points it brings out. This drives it home to the salesmen with permanent effect.

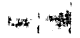

If conditions are such that the publication for which you work cannot furnish you with statistics regarding circulation, rates, retail conditions and 
the market, dig it up yourself and be a regular encyclopedia of advertising information.

You can buy very reasonably illustrated services, including the matrices, which will give you the latest styles in wearing apparel, home furnishings, bargain sale illustrations, etc., which can be used profitably in preparing ads for advertisers.

Think big-but don't oversell the advertiser. Small copy in the beginning and full pages for years is better than a few full pages today and nothing tomorrow. Always follow a hunch. If the suggestion comes to you that it is about time for John Jones to start his fall campaign follow it up, as that is the beginning of an idea that can be sold to advantage.

It's easier to lead the merchant into thinking your way by the power of suggestion and salesmanship than it is to bluff him or try to make him think he is a dumbbell and doesn't know his business because he doesn't think as you do. Remember that most of the merchants have substantial and profitable businesses as evidence of their correct thinking and effort, while you are just starting out with no evidence of your ability to exhibit.

In preparing copy for advertisers remember that women represent 85 per cent of the buying power of the United States. Their influence is not always visible, but it is an established fact that most men are guided in their purchases by subtle suggestions from some feminine member of the family, or prospective member.

Guard against creating an atmosphere in your copy that the merchandise is for an exclusive few, as there is danger of creating the impression that the price is high.

Remember that only 6 per cent of the people of the United States have an earning power of $\$ 3,000$ a year or more.

Advertising is a more profitable vehicle of publicity to sell merchandise which appeals to the substantial middle class than to the silk stocking group.

See the advertiser as often as necessary and have him feel that you are an adviser and a help, rather than one who is merely taking his money to pass it to the publisher.

National advertisers and advertising agencies, are vitally interested in three things. The market, distribution, and selling. Therefore, in working this field, make a thorough study of your market to determine its potential possibilities. This can be done by a canvass through jobbers, dealers and homes, or through data which is available through the various government and state departments. The United States Bureau of Census can give you interesting information regarding the population, earning power, spending tendencies, home ownership, etc., of your particular market.

Assist the advertiser in getting distribution so the merchandise will be on the shelves and prominently displayed ready for the customers which advertising will bring to buy. When a salesman comes to your town, introduce him to the principal jobbers and supply him with a portfolio containing a letter signed by the advertising manager or manager of the merchandising department of your paper, indicating the lineage to be used, and include proofs of the advertisements, if they are available. If the advertiser is willing to pay the expense, offer to send a letter to the jobbers and dealers in your town, outlining the advertising campaign and urging the dealers to give the goods 
prominent counter display and a window showing, if it is consistent. Always encourage a new advertiser by giving good position, as it will more quickly stimulate sales and encourage the advertiser to use more space. Remember it is to your in terest, as well as the advertiser's, to make the advertising pay.

The national department of a metropolitan newspaper is not subject to the close, daily application we find in the local field, as the method of securing and creating national advertising is somewhat different from that of the local salesman. In the national field circulation knowledge and merchandising co-operation are important factors, as the space buyers and the selling members in advertising agencies buy space on the basis of circulation coverage, and cost per line per thousand of circulation, coupled with the selling power of the medium and the effort the newspaper will make to help merchandise the goods.

There are two established methods of securing national advertisingeither is good. One is called "direct" representation and the other "special."

Direct representation is having your own salesmen covering the national field exclusively for your publication, the publisher paying all expenses. Special representation through is an association with an organization that represents a number of other newspapers. They do all the traveling and usually operate on a drawing account and commission basis. The latter form of representation is preferable for semi-metropolitan newspapers.

The promotion and Publicity Department plays an important part in furnishing the advertising salesmen helps, and in developing advertising. Newspapers should use their own advertising columns more as a means of selling advertising and creating circulation. It is surprising how much additional advertising can be developed through special promotion work. A number of years ago the Post-Dispatch conceived the idea of staging, twice each year, what we call Real Estate and Home Investment Weeks, and Used Car Weeks. All of the promotion matter, publicity and tie-up for our next Used Car Week was prepared in our Promotion and Publicity Department. In preparing the promotion work we adhered to five fundamental ideas: First, to create buying interest in the reader; second, to convince the advertiser that it was a profitable time for him to advertise; third, to create more lineage; fourth, to create good-will with the dealers; and fifth, to pep up our own selling organization. A folder was mailed to all automobile dealers in connection with our Used Car Week. A quota was set for each classified salesman to reach during the week. Each day he was informed whether or not he had made his quota. Bonuses were offered for special accomplishments. Cash prizes were offered for full pages, half-pages, quarter-pages, etc. Needless to say, the effort has proven profitable.

Classified advertising is one of the important features of a newspaper, as it not only has big revenue possibilities, but influences considerable circulation. The rate should be as low. as you.can profitably make it in order to get volume. After you have built up the volume then establish the proper rates, unless you prefer small volume and high rates.

Keep the fakers out of your columns, as their misleading and fraudulent advertising will destroy reader confidence and impair the responsiveness.

Light-face type in the classified columns is preferable to black-face as it 
gives a uniform appearance to the page, and does not give one advertiser an advantage over another.

Three sources are suggested for developing classified advertising: Direct salesmanship, telephone, and mail. Salesmen are usually employed on a commission and salary basis, with bonuses for special accomplishments. They can be assigned by districts or by classifications.

Considerable extra advertising can be secured by encouraging the public to telephone ads direct to the paper. Also by telephone solicitation, using competent and well-trained girls.

In the height of the season the Post-Dispatch employs fifty experienced girls Saturday for telephone work. It is a common experience for us to take in more than 4,000 ads over the telephones for our Sunday paper Saturday afternoon and evening. More than 3,000 ads have been received in several hours Saturday night for the Sunday Post-Dispatch.

More than 12,000 classified ads have appeared in a single issue of the Sunday Post-Dispatch. An investigation made some time ago showed that there are almost 100 possibilities for a mistake of some kind in handling a classified advertisement; therefore you can appreciate the careful attention each advertisement must have.

Minimize errors in classified ads as they frequently mean loss of the profit in a sale to the advertiser and the loss of a customer to the newspaper.

Direct-by-mail methods can be employed to reach advertisers in developing certain lines of classified such as farms for sale, agents and salesmen, and resorts.

Take your advertising men in to your conficlence. Let them know whether you are gaining or losing in circulation and advertising. Frequently they have good suggestions, which can be developed into sources of revenue. One idea suggested to me by an advertising salesman was worth $\$ 75,000$ a year to the publisher.

Keep a careful record of each man's work, showing the number of contracts he produces, the volume of new business he creates each month, the total lineage and revenue he is responsible for, and his rank compared with that of the other members of the staff.

Where you have large enough staffs you can divide them in to groups and create rivalry, and incidentally, considerable business by holding contests of various kinds. One contest we had on the Post-Dispatch brought in more than $\$ 25,000$ worth of new business contracts in one month. We organized the staff in to two teams: one the Cardinals, the other the Browns. A point system was worked out whereby contracts scored a hit, two-bagger, home-run, etc., depending on the size of the contract and the circumstances.

The last few days the contest became a mad struggle for new business. One salesman bagged his last contract a few minutes before midnight the last day of the contest, and got me out of bed to tell me about it so it would be certain to count.

The Merchandising Department and the Research Bureau are both service departments to assist the National Department in creating more advertising. The Research Bureau analyzes the market and develops information regarding certain products which the National Department can use in selling the advertiser the idea of utilizing the advertising space. The Research 
Bureau of the Post-Dispatch can give you a complete picture of the city showing vital information which an advertiser should have in considering the possibilities of the market. For instance, we can tell you the number of telephone users in every section of the city; the average rent paid in the respective sections; the number of grocery stores, drug stores, garages, radio dealers, hardware, shoe stores, etc.; likewise, the population and whether or not the section is densely or sparsely populated, and the character of the population.

The Merchandising Department comes into play both before the advertising is started and after the campaign is under way. The advance help is given by routing salesmen via our carefully compiled and up-to-date route lists. For instance, a salesman can start with the first call nearest the Post-Dispatch and by following our routes he can cover the entire city without retracing. We have route lists for all of the important retail and wholesale lines. This department also gives merchandising assistance by instructing and directing salesmen and handling the detail in connection with promotion literature which the advertiser may care to have distributed.

A staff of trained men is employed to gather merchandising information so the advertiser may know the status of his particular product as compared with his competitors, how the goods are moving and suggestions which the men are in a position to gather by contact with the trade.

After twenty-five years of close contact with various phases of newspaper work, I can say to you who are about to embark on the seas of journalism that you have selected a most fascinating occupation. The atmosphere of the newspaper plant is surcharged with surprising acitvity. There is no monotony. The days are crowded with new problems which must be met and solved in the moment. Life's tragedies and comedies pass in endless panorama, but through it all the serious responsibilities of the newspaper worker become stimulants and inspirations which return abundant compensation.

The Post-Dispatch invites you to come to St. Louis at any time to inspect our modern newspaper plant and to ask any questions you desire.

\section{Getting National Advertising for the Country Newspaper}

\section{By James O'Shaughnessy}

\section{Executive Secretary, American Association of Advertising Agencies}

Without the country newspaper is it possible for the national advertiser to be a truly national advertiser?

Can truly national advertising be done without the use of the country publishers' circulations?

Or to put it another way, can a truly national campaign of advertising be made without using country newspapers?

Someone may ask me at this point, What is a national advertising campaign?

Is it a campaign whose parts touch every state, some of them only lightly?

If it does not reach to every reader in every one of the 3,063 counties, is it a truly national campaign?

Is it sufficient for the hypercritical that a national campaign of adver- 
tising is such if it reach the predominant majority of the firesides in all of the 3,063 counties?

A better answer may be got perhaps by dividing the question by fortyeight. Can a state campaign be made in this highly typical state of Missouri without using country newspapers?

I should not like to leave the impression that the phrase, "National Advertising" as generally used, is improper or inaccurate. "That phrase is correct in the idiom of the advertising business.

A campaign of advertising which covers a substantial percentage of the homes in two or more of the four great commercial divisions of the country, may be, in the language of advertising, properly called a national campaign.

The use of a reasonable bulk of the nation-wide circulations may also be properly called a national campaign. It is equally true to say that the use of metropolitan newspapers could make a national campaign. And so could a possible use of the outdoor medium. The expression goes largely by courtesy justified by the custom of the industry.

Under this courtesy is the thought that advertisers operating in the wide markets have more extended and intensified activity as their goal.

Also, it may be true as to some products that the bulk of the entire national market is actually covered.

National campaigns and the national market are observed, under analysis, to be groups of more or less defined units of territory on one hand, and local markets on the other. Some markets larger, some smaller, some compact, others scattered.

Sometimes the advertising campaign grows from the coverage of a local market until it has consolidated enough contiguous markets to give it a national name. Other advertising campaigns begin with the upper tips of markets all over the forty-eight states and spread downward, in the latter case using the national circulation units.

Advertising campaigns are planned from many kinds of starting points, and with many kinds of views, but with all their variances in beginning, they crystallize into exactly the same thing. It may be called profit-finding, or business building, or institutional anchorage.

The campaign may be to gain a market, or having a market, to find increase in it; or, as is of ten the case, to hold the market against new competition or old competition newly in tensified.

Whatever the case may be, the advertising campaign is planned for economies and it produces them or it passes.

The work of making plans for national campaigns and executing them through the manifold and ever-growing intricacies, is the work of the advertising agency.

The advertising agency is a rather new thing. It was once an advertising agent. There are many publishers at this convention who remember that time. Later it grew into more than one man's work. That called for organization, and what was an agent has become an agency.

It grew to meet the enlarging demands made upon it. Today we find the agency organization rounded out with the aggregate skill of many callings.

Those who write have only one of the many skills assembled to make the roundness of the modern advertising agency organization. Some of the others are in research analysis, market measuring, planning, media, accountancy, transportation, and of course, art in several of its expressions. 
Since so much and various knowledge and experience is necessary to round the work of the advertising agency today, that fact forms a complete answer to the question of why the manufacturer must have an agency if he is to negotiate the broad markets successfully.

National advertising calls for the answer to so many kinds of questions, the answer to any one of which may be needed any day of the year, that the manufacturer with problems of his own cannot do all the things his advertising requires. If he neglects one of the things it may mean a breakdown of the advertising undertaking.

No good business man wants unnecessary help around him, and yet we find the great successful national advertisers employing advertising agencies.

Sometimes we hear that these agencies use the big units of circulation, to which I have referred, because they make a large amount of money on a small amount of work. That answer is so easy to believe that a simple contradiction is not always sufficient. It is better to look at what lies beneath.

The advertising agencies, except in rare and indefensible instances, do not make money out of advertising failures. To say that they do is just as unfair and untruthful as to say that all merchants sell ill-gotten goods, or that all newspapers lie.

The fact is that merchants must be honest in order to prosper. Newspapers must tell the truth or they cannot continue. Advertising agencies must make money for their clients or their clients will not go along with them.

The record of advertising agency operations show that the net profits of the agencies composing our association come out of successful advertising campaigns. All campaigns that fail, and fortunately there are few, have brought losses to the agencies handling them.

The operations of the business require that the advertising agency place the advertising where in all circumstances it pays best, whether it be in a single insertion costing $\$ 7,000$, or in ten inches in a country weekly costing $\$ 4.20$ per insertion. Every order issuing from the advertising agency is guided by the desire and the purpose to make success for the advertiser. That is selfish on the part of the agency because its success can come only out of that of the advertiser.

Then why does not the advertising agency use more space in the country newspaper?

If to be a truly national advertiser one must use country newspapers, then why is it not more generally done?

The shortest answer to that question is that the country publisher generally has not sufficiently removed the economic resistance-and it is purely economic. It is true that in Missouri these chief obstacles or resisting things have been removed.

First, you have organized the state and brought into the organization the overwhelming strength of Missouri's country newspapers. I believe it is true that every good newspaper in the state is a member of the Missouri Press Association.

Second, you have printed the list and published it to the advertising agencies. In that list you have given the figures for circulations and rates, and to the accuracy of these circulation figures and the fairness of the rates you have given the approval of your association.

Third, you have provided that all of your newspapers can use mats. The mat for a page costs, delivered, about 60 cents, and plate for the page, 
delivered, would be about $\$ 6$. The average cost of a page in a Missouri country newspaper is about $\$ 34$ with only 60 cents mechanical cost to the advertiser. In bare cost, the plate would carry a penalty of $\$ 5.40$ per page. Since that additional cost represents waste, it is repugnant. Since it is that much money, it is forbidding.

Missouri has removed these three chief obstacles to national advertising lineage. It has done all that I suggested to your convention in St. Louis. I said then that these things must be done before you could get your proper share of national advertising. You have done them, and yet there are those here who may ask why more lineage does not come.

The first part of the answer to that question is that advertising media are grouped or classed. The country newspapers are a definite class. To use them in national campaigns means they must make a national picture.

The adjoining state of Iowa has made the same progress as Missouri; and yet two states alone do not give a national complexion of the country newspapers.

The state of Washington has done the same thing. If, instead of Washington it were Illinois, or Kansas, or any contiguous state, it would have more influence at the moment.

If, however, all the states in the union were in the advanced position of Missouri, Iowa, and Washington, then it is reasonable to believe that wide campaigns over the country circulations would begin to multiply.

With only three modernized states you are obscured by the 45 more or less antiquated and largely unusable states.

I do not mean to infer that you must wait until the country publishers in all the states rise to your plane before you can come in to the vision of a national advertiser. If the central states from Ohio to Kansas inclusive, could make the same offer to the national advertiser it would be a vastly different story. That would provide a mass that would bulk in to the national vision.

But that means waiting on someone else who may be asleep. There is much you can do yourself. Missouri is not a national market but it is a tremendously big market none the less. It is more than $1 / 48$ of the national market-it is nearly twice that large. More than half the people own their own homes; and 54 per cent of all Missourians live on farms and we know what newspapers they read and actually do read.

Cities of between 2500 and 5000 could properly be counted as rural because their people are there to serve the farmer only.

There are only thirteen cities in Missouri with more than 10,000 population and all of these together have scarcely more than a third of the state's population.

You have, therefore, as your market to deliver, more than two millions of people whose buying power the average advertiser is not likely to question.

You have an abundant offer to make to that advertiser who is big enough to take a market of this size.

In the national consideration it is a new offer. Unless Missouri, or Missouri and Iowa, are forward in the distributor's mind, it is easy to turn to the medium of wider territorial possibilities.

The national advertiser can think of Missouri country circulations as desirable since they are economically available. 
Your organization plans, as now perfected, appear to me to be adequate. The method you have adopted of presenting the Missouri list to the advertising agencies needs only to be continued and your efforts made more emphatic as you proceed.

We Missourians ask others to show us what they are trying to sell to us. Pay the other fellows the compliment of thinking of them as if they were Missourians. Show what you have to sell to the national advertisers, explain all its values and virtues and keep explaining until they not only know but appreciate. Then the sale will follow.

\section{Building a Classified Page in a Country Weekly \\ By W. Earle Dye \\ Editor, Richmond Missourian}

Classified want ad advertising is a public necessity, and the sooner that the country newspapers awaken to the opportunity which is knocking at their doors, the sooner they will increase their bank accounts.

As far as classified want ads are concerned, all communities are alike. The need for want ads is there, and the opportunity is present-the volume of business of course is dependent on the density of population and other business factors.

The development of a classified want ad section in a country newspaper opens up a legitimate field of profit and a broadened horizon of service to the community at large.

Aside from remuneration which want ads afford in a direct way, they form the most human kind of news that can be furnished to your community, and they are circulation builders of the first order. Certainly nothing is closer to the heart throbs of a community than its daily needs. The most universal want that was ever uttered is "Give us this day our daily bread," and that, in its last analysis, is what every want ad printed in a newspaper really means.

Historically, want ads are as old as the human race. They may easily be found in many places in that Book of Books, through a little careful reading between the lines. Perhaps the most far-reaching want ad ever published was on those ideographic tablets of the Pharaoh dynasty, which directed the Israelites to appear in their thousands to make bricks without straw for the public buildings of Egypt.

Then out of history's pages comes another want ad printed on tablets of wax, indited with a stylus, and posted in the market places. It was that "want ad" of Herod, king of Judea. "Wanted, the King of the Jews," which brought forth no answer. Then followed the massacre of the innocents which brought forth Rachael "weeping for her children and will not be comforted for they are not."

And, so it goes down through history. Long, long before books or newspapers were printed, the want ad was present in a variety of forms, remaining in the customs of peoples of different lands. The matrimonial want ad was indicated in the dress of the maiden as distinct from that of the married woman showing that a husband was desired. From that custom, our wives have had us provide engagement rings for them, so that they could show the other girls that 
they had had an answer to their "want ad," and then after marriage the wedding ring was provided to show the world that they wanted, were wanted, and got results from their advertising. Some wives, imbued with the effectiveness of their wantads, even go so far as to have their husbands wear wedding rings as a sort of silent want ad warning to the other women.

There are a number of methods of want ad promotion. Of all, direct solicitation in its various forms, is probably the best and most effective. Every one of you comes into contact with thousands of people every year: in your offices, on the streets, or in gatherings of various kinds. Every time you meet a person, you have an opportunity to solicit want ads. When a man comes to The Missourian office to pay his subscription, or for other business, I try to bring our want ad page to his attention, and find out if he has anything for sale, or if he needs any thing. More often than you imagine, I secure a want ad.

In promoting some of our want ad business $I$ have used circular letters in a very successful manner. Early in the spring I prepared a letter directed to the Ray County poultry raisers, in which their egg and baby chick advertising was solicited. This brought good results, and during the present season I followed up the original letter with others from time to time as the situation demanded. I have used these circular letters in soliciting other lines of business with varying degrees of success. One letter which I sent out recently to a selected group of want ad prospects totaling 111 names, brought in $\$ 27.16$ worth of cash business in less than ten days time.

Another method of promotion which has been used by some other newspapers and which we have used quite successfully, is a coin mailing card. Ads from non-competing newspapers are clipped, pasted on the blank provided on the card, the figured cost of insertions placed in the spaces provided, and the card sent to the advertising prospect. A surprisingly large number of these little cards come back with the money in them.

Perhaps the simplest method of want ad promotion, and one which certainly should be used, is advertising in your own newspaper. All of us preach advertising, but too few of us really use it. In some respects we might be like a barber who never shaves, or a shoemaker who goes barefoot. The barber, of course, can't build up his business merely by shaving himself; nor can the shoemaker build trade by merely going shod. But our newspapers go among people who have daily needs, and there is no reason why we should not use our own mediums to increase our own business.

Well-timed, and well-written promotional advertising, aimed at a mark, is sure to bring in returns-if it is kept up long enough. The Missourian uses an advertisement, advertising classified advertising on its classified page each week. This is changed in style and illustration every other week, but the theme is the same. Then, in addition, we are using a series of small one-column promotional ads scattered through the paper. We do not use these ads to fill up space, and I do not believe that any of our subscribers can accuse us of doing that. We use these ads for exactly the same purpose as any of our other advertisers. As a matter of fact, I believe that we have created advertising confidence in The Missourian because we have been using it successfully to build up our own business.

The type of newspaper promotional advertising which should be used, of course, depends upon the newspaper in question. A newspaper which is building up a classified want ad section should advertise for both readers and ad- 
vertisers. A newspaper which already has built up a good classified business should advertise for readers. It is my belief that the fundamental idea of classified promotional advertising should be to make the readers of your newspaper read and take an interest in your want ads. By getting people to read and answer the ads, you are advertising indirectly for more ads, so that you accomplish both purposes with one kind of advertising.

Summed up briefly, the promotion copy that tells the reasons why one person should read the classified columns is telling the same reasons why another person should advertise.

Along the line of promotional advertising comes the use of testimonials regarding the results obtained from want ads. Suppose that someone comes to your office and inserts a "For Sale" want ad, and that he immediately secures more buyers than he can supply. The fact that he does will make an interesting news story, which at the same time will promote your business. We use such stories frequently. For instance, several weeks ago we had a farmer friend insert a want ad for one week, advertising some livestock. Within three days he had disposed of $\$ 445$ worth of the stock, divided among widely scattered buyers. We took his results, wrote a front page story, and used his ad for a catchy display on the classified page. As a direct result from his success, we got more business from others.

Of course every want ad will not bring immediate results. If such were true, we would all have more want ad business than we could possibly handle. But want ads do bring results more often than they fail, and for that reason they are good business investments.

Christmas time offers an excellent opportunity for building up want ad lineage, in a manner which will give you considerable volume with a minimum amount of effort, and at the same time create an impression which will last long enough for you to establish a want ad section large enough to be noticed.

Every store catering to any kind of Christmas business is a potential classified ad user. Every store has a number of special articles which would sell very readily if they were advertised, but the profit on each item is so small that very little can be appropriated for advertising them. Here's where your opportunity comes in. Suggest a classified ad in your Christmas classified want ad section, under the heading "For Her", "For Him," "For the Children," "For the Family", "For the Home," or "For Dinner or Decoration."

Last year The Missourian purchased a special Christmas want ad service which promoted this idea, and we were very successful with it. In five weeks we ran 541 ads, which brought in a total of $\$ 200.90$.

In short, the promotion plan was this: Several weeks before the Christmas advertising was due to start, we began a small direct personal campaign among the merchants telling them of the new service which we had to offer, and which would assist them in creating Christmas interest.

To our subscribers we directed another campaign, telling them of the Christmas gift suggestion department that we would have for them. The result was that we created interest in the department before it had actually appeared in The Missourian. During the week before Thanksgiving, I made the rounds of our advertisers, as well as the non-advertisers, and carefully explained the plan. A sample dummy layout made it easy to show concretely just how the ads would be placed in alphabetical order and under the proper headings. 
The idea took with both the advertisers and the readers. The advertisers liked it because it gave them an opportunity to advertise small purchases of special merchandise at low cost. The readers liked it (and many of them said they did) because it offered them a weekly catalog of the best gift suggestions in Richmond.

I imagine that some of you folks are making mental reservations right now, saying, "Well, The Missourian might have run several pages of Christmas want ad suggestions, but what about their display advertising." In spite of the fact that merchandising conditions in my locality were not as good at Christmas time as they had been in some years, our display advertising for Christmas 1924 equaled that of the average of several years prior, and the Christmas gift want ads brought in additional revenue.

As a matter of fact, we had a number of advertisers using our Christmas gift suggestion page who had never before bought display advertising. They got results and now they are developing in to display advertisers.

I am telling you about our Christmas classified page, because it leads up to further promotion ideas. Before Christmas our volume of want ad advertising was very small. After the first issue of the Christmas classified page, it began to jump. Instead of lumping all of the ads under one heading, "Want Ads," I added the world "Classified" and saw that appropriate headings were set for each type of ad. The result was noticeable immediately. More ads began to come in than we had ever before handled. People began to get better results. Not only that but I would occasionally hear a non-subscriber comment that he had heard "so-and-so" speak about the classified section of The Missourian. As a result of our Christmas want ad business, a permanent classified want ad. section has been estabished, which is enjoying a steady, heal thy growth.

I believe that all want ad advertisements should be grouped together in one section of the newspaper, rather than be given the "run of paper." Your want ad section is a department store. Suppose that Marshall Field, in Chicago, should have safety-razor blades in their basement store, safety razors on the fifth floor, shaving brushes on the second, and shaving soaps in another place. How much of each would they sell?

Yet a number of newspapers, and I am making the criticism in a friendly manner, are doing just this same thing-scattering their want ads at any place in the paper, wherever they have a few lines to fill.

This practice $I$ believe is unfair to the advertiser, unjust to the reader, and hurtful to the publisher.

It is unfair to the advertiser because he has no definite location and his ad is of ten overlooked. The want ad advertiser, while he is a small user of space, is the highest-priced advertiser in your paper and is therefore entitled to some consideration.

It is unjust to the reader, for it forces him to take time to minutely search through the columns for what he needs-and while there is no question but what country newspapers are more closely read than any other, small items may be overlooked.

The practice is hurtful to you because you fail to make the reader impression that you might if you put all of your ads together, and thereby made a better showing. It is unfair to you because it forces you to hunt for the small ads when you post your books. Classification or no classification, a dozen want ads grouped in half a column make a better impression and give better 
results than three times as many want ads widely scattered through the paper.

After the ads have been grouped together comes the question as to their proper classification in divisions. This may be done simply. Where there is less than a column, they can probably be grouped under two divisions"Wanted" and "For Sale." These two items cover the general field of want ad advertising.

These major classifications do not suffice at all times. In the spring of the year, when poultry and field seed advertising may be developed quite extensively, additional classifications might be added. Our poultry and egg advertising is grouped in two sections- "Baby Chicks" and "Eggs for Hatching." The logic of the division is this: With no more time or trouble two important items have been assembled in such a manner as to make them readily accessible to the readers. And a possibility has been created for more business, as 90 per cent of the poultry breeders have both eggs and baby chicks for sale and they will want an ad under each division.

This division holds true under other "For Sale" and "Wanted" classifications. We carry such other classifications as "Used Cars," "Help Wanted," "Situation Wanted," "Lost and Found," "Business Service," "For Rent," and "Announcements," using the headings whenever business demands them. Our general rule has been, where we have three or more specific ads, to group them under a specific classification. This rule, obviously, could not profitably apply where business return does not justify.

We carry our classifications still further. All items are listed in alphabetical order. For instance, whenever an ad comes in to be listed in the "For Sale" column, we set the object listed in black-face type at the beginning of the ad, forming a key-word, and place the ad in the proper alphabetical sequence. This makes our classified section as easy to use as a dictionary.

The question probably arises, will the promotion of classified want ad advertising cut down display advertising? As far as the average country newspaper is concerned, the answer is NO. Want ad advertising appeals and is generally for the small advertiser who does not ordinarily use display space.

On the other hand, want ad advertising not infrequently creates display advertisers. The non-advertiser finds what a want ad will do for his business, and he develops in to the larger use of space.

Give just a little time to building up a want ad department, and in a very short time you will find that you have started a snow ball down hill, which will grow larger and larger as it progresses, and finally it will gain such momentum that it will keep going of its own accord.

\title{
Watching for Fake Advertising
}

\author{
By R. C. Ferguson \\ Editor, Buffalo (Mo.) Reflex
}

There is always a business end to everything, bumblebees and newspapers not excepted. My subject has to do with the business end of a newspaper. Now I have made no particular success with the business end of publishing a newspaper, and would not have you think I pose as an authority on such. But I have had some experience with fake advertising. Since misery loves company, I am going to venture the assertion that I am not the only one pres- 
ent today who has been faked out of some space or been made a tool of to fake others.

Had I the talent of Bud Fisher or McManus, I should draw a comic something like the following: To begin with, a country editor is seen trudging to the old shop some blue Monday morning. He passes his neighbor, the banker, and a carload of other fellow townsmen with fishing poles in evidence and the old car headed toward the river. He grits his teeth and goes on. In his mail this morning he finds a letter which makes him forget his troubles-a liberal order for advertising from the Skinner Oil Company, of Flukeville, Tex., with instructions for immediate insertion and to bill at the current rate. He transports it back to the composing room with light step and a smiling face. Business is good.

Well, the ad appears that week, the next issue, and the next. Mr. Editor remembers his wife has bought a new coat this month, and that his life insurance comes due the 5 th of next month. So he gets the checking copies and his bill in Uncle Sam's hands a few days before the last of the month in order that Skinner Oil Company's remittance will be back in time to help out. The first of the month rolls around, the second, third, fourth, and fifth; yet the expected remittance has not shown up. He thinks maybe his letter went astray, and waits till the tenth. Beginning to suspicion that all is not well, he hunts up the advertising order to get the name of the officers or some individual connected with the company to whom to write a personal letter insisting on his money. Why, yes, here the secretary has signed it. Mr. U. R. Stung is his name. "U. R. Stung", the editor repeats. The picture ends with Mickie, the printer's devil, administering water to the prostrate form of $\mathrm{Mr}$. Editor.

Of course this is somewhat overdrawn, as most comics are. Not all fake advertising these days has the easily distinguished earmarks that the Skinner Oil Company's did, for since editors are becoming a little more watchful, fakers have increased their slyness accordingly.

No publisher loses much individually, as a rule, by publishing fake ads. The fact is, he soon gets his capacity of unrewarded service, for a little of that goes a long way. Although our individual losses may be small, the profession loses a handsome total each year by fake advertising.

Besides the kind of fake advertising which purports to beat the publisher is the kind intended to fake his readers. In most cases this sort is illegal; yet there may be a few cases where it is not illegal, but wrong morally. So I am including morally wrong advertising along with strictly illegal.

Quite often it may be the case that a questionable ad be sent you with check inclosed. The bad intention and hurtful part here is that some of your readers will be misled, cheated, deceived, or swindled.

As for illegal advertising, the postal laws and regulations, and the statutes define it, and I need not do more than mention that anything depending on lottery in whole or in part, any assertion, representation or statement of fact concerning merchandise, securities, service, or anything offered which is untrue, deceptive, or misleading is illegal matter for the advertising columns of a newspaper.

It is the duty and should be the policy of every newspaper to avoid all questionable advertising for at least four reasons:

In the first place, it entails financial loss to the publisher or his readers almost without fail. This alone is sufficient reason to justify its avoidance. 
Then it is a fact that nothing so shatters the confidence of readers in the advertising medium and in advertising in general as for them to experience some loss or be victims of misrepresentations as the result of having responded to an advertisement. And the publisher himself feels like Old Dog Tray at having published such matter. While the publisher is not held responsible under the law for publishing fake advertising without knowledge of its unlawful nature, he should throw out interference against such for the sake of his readers, because the honest advertiser, the publisher, and in fact the readers themselves suffer greatly when readers lose confidence or interest in advertising. And this is a sure result of their being faked.

A third reason for avoiding fake advertising is that the publication which contains it is liable to suspension from the mails.

There is an old saying, "Darn the fellow who won't take a chance." It's true that one often has to take chances in life. My wife had to take a great hig chance when she married me. And I'll wager that most of your wives would be considerably more careful if they were left widows and free to marry again. We have an unmarried lady printer at our office whose motto in regard to marriage is "Better be safe than sorry." It is to her credit and might I say "profit" that she has adopted this motto. I believe it would be a pretty good one in regard to fake advertising. I hope you will note and remember it,- "Better be safe than sorry."

Because a solemn principle of right and justice and golden rule dealing is violated is my fourth reason why we should steer clear of false advertising. I believe there are few publishers but what desire to have their publications enjoy a reputation for reliability and integrity. There are exceptions, of course, in greater or lesser degree. There are those who are so money mad or so poverty stricken that they're like a bass at spawning time,-bite at anything that comes along. Sometimes such base reasoning as this causes a doubtful ad to be run. "Well, I have to fill with up something and if this ad is never paid for or is unreliable it will kill that much space; so here goes." Friends, a deceitful ad may do much harm in the ways I have mentioned, while some white space won't hurt anything unless it is your conscience for not getting more news. So "Better be safe than sorry." Leave out the ad and lead out a little more.

Our ideals of newspaper morality should be so high and our realization of a newspaper's duty to society so keen as to cause us to shun the very appearance of shady advertising.

How is one to distinguish fake advertising? It is evident the publisher has the major portion to do here. The fake advertiser is trying his best to cover up his trickiness. It's like the lady in the jewelry store who asked the clerk, "How does one tell imitation pearls from real ones?" He replied, "My good lady, one does not tell, one keeps it to one's self."

It is a comparatively easy matter to winnow out the bad pay advertisements. If a concern is $\mathrm{O}$. $\mathrm{K}$. they do not resent inquiry but rather respect you for it. No one places a higher value on your space than you. So be careful about giving it away and thus increase its value and command the respect of advertisers.

But as to the honesty of the ad itself-that is a much more difficult and particular matter. The publisher is left largely to his own resources of common sense. 
One outstanding earmark of irregular advertising is that it offers more than value received. Not all bargain advertising is fake, but it's pretty sure that all fake advertising offers great bargains. Careless and extravagant statements give evidence of bad policy if not bad intentions, and should be looked at through a question mark.

Others want a small sum of money sent by the reader for a sample of something, and when the money is sent that is the last of it. I'll not attempt to enumerate the many, many kinds of fakes which may be offered you. I do want, though, to impress upon you the necessity of avoiding them.

Suppose you were financially responsible for every bit of advertising in your paper, and had to reimburse every loss or repair every disappointment which it occasioned; how vigilant and extremely carefu! you'd be about what composed that advertising. We should as unselfishly guard the interests of our readers as we would selfishly guard our own.

Not all fake advertising is "foreign" by any means. Very often we find a home merchant who wants to practice the circus style of advertising originated by Barnum, and thinks that to be effective, advertising should be high sounding and extraordinary. Such phrases as these are his mainstays: "Was $\$ 10$, now $\$ 4.98$." "Worth $\$ 1$, now 39c." Or an article is represented as "best quality" and offered at a third-grade price. It is most likely no wilfully wrong intention is in his mind, but rather a bad habit in his make-up.

Fake advertising - how are we going to combat this immoral parasite and business nuisance? As long as there are public carriers of advertising, just that long will some fakes get by. But I am convinced that publishers can readily bring such to a minimum by proper precautions which lie easily within the reach of all.

First, we must have the united effort of all. It is evident that if everyone were sufficiently alert to the faker there would be no faking. So I plead that everybody investigate all doubtful advertising before running it. Satisfy yourself before you lose your space or carry a harmful message to your readers. Adopt the policy of cash in advance or satisfactory reference.

Our good executive secretary, Mr. J. S. Hubbard, offers his efficient service in looking up doubtful concerns and passing the results, good or bad, on to the fraternity through the "Missouri Publisher." Let's stand together by using him and being governed by his findings. Then as individuals we can pass along any experience we have had with a bad advertiser which will be profitable to our neighbors. I remember seeing some advertising in one of our exchanges one time which we had been unable to collect for after running it in the Reflex a few months before. I wrote the editor, and, I believe, saved him a loss. He published a part of my letter, stopped the advertising, and no doubt found upon investigation that the concern was bad pay.

In the case of the home merchant who is inclined to use the circus style of advertising, we can tactfully help in preparing the copy when opportunity affords, and run articles in our columns holding up the idea that only really truthful advertising pays. It would be a commendable, and I think, effective way of insuring reader confidence and producing sufficient care among advertising patrons, if the publisher would keep a standing offer to make good any loss sustained to responding to advertising in his columns. This would demonstrate the publisher's confidence in his merchants which would surely be met by care on their part to live up to their advertising. 
After all, my subject is just one of the many phases of newspapering which calls for the best there is in us to meet and solve them. It's just a part of the busy world, and the schooling of life. And

When things go wrong, as they sometimes will,

When the road you're trudging seems all up hill,

When the funds are low, and the debts are high,

And you want to smile, but you have to sigh,

When care is pressing you down a bit,

Rest, if you must, but don't you quit.

So, in the language of Paul, the apostle, I say, "Watch ye, stand fast in the faith, quit you like men."

\section{Advertising From the Viewpoint of the Country Merchant By John H. DeWild \\ Manager of the Merchants' Service Department, Ely \& Walker Dry Goods Co., St. Louis}

I am glad to be where there are present so many newspaper men who are interested in the retail merchants-and I assure you that what I shall have to say will be practical and based upon a number of years of actual experience in advertising work.

It is twenty-seven years since I started to learn how to set type in a country newspaper office in central Iowa. My father was at that time a country merchant-but somehow I gradually grew into newspaper work. And after serving as a country and city printer for eight or nine years I edited a country newspaper for four long years.

During these years of calling upon the country merchants I tried to help them in writing advertising copy that really meant something. And it was during this time that I somehow or other got the idea that there was more money to be made by entering the advertising field in the larger cities. I had an ambition to become advertising manager of some large city department store-where I imagined the work was easy and the salary large. So I sold my country newspaper and went to Minneapolis. For a number of years I served as advertising director for several of the largest department stores. In this work I found my ideas of compensation somewhat reversed-the salary was none too large and an immense amount of work had to be done.

However, this was excellent experience-and the idea kept coming into my mind that all of the modern ideas of advertising and merchandising as practiced by the large department stores could be used to advantage by even the small-town general stores.

With this thought in mind, I believed there was an opportunity to do a great deal more for the retailer who did not have the means to employ permanently an experienced advertising manager. For four years I served as assistant advertising manager of a large daily newspaper, taking care of many accounts and writing a great amount of retail advertising copy for the smaller merchants and specialty shops. Then came three years of trade paper experience and three years of work with manufacturers and wholesalers in directly assisting the smaller retailers. 
And in all these years of experience, there are two important points that stand out as vital in the retail business:

The first important step in conducting a successful retail business is that there must be a merchandising plan. Merchandise must be carefully and intelligently bought. The important sales events of the year must be planned in advance.

Then, your advertising must be planned and a campaign formulated that will "mesh" with your merchandising plans-just as two perfectly fitting cogs "mesh" in a delicate piece of machinery.

For instance: In the large department stores, much of the planning is done several months in advance. In October and November a great deal of planning is done for the approaching January clearance-sometimes even to the extent of laying out a schedule as to space some of the departments are to occupy. Yet in most of the small towns I have visited $I$ find retailers preparing advertising copy on the spur of the moment, "shooting" it to the newspaper officeand then wondering why they do not get satisfactory returns.

It was mentioned this morning that the retail merchant does not plan his advertising campaign sufficiently in advance-and it is true. There should be a definite amount appropriated to cover the various months and important events of the year. And in this connection it is possible for the newspaper publisher to assist the retailer in the preparation of his advertising, and in writing copy that would be more descriptive with least expense to the merchant.

Lack of descriptive, interesting advertising copy has caused many papers to fail as advertising mediums-because in many of such communities the readers of the paper have not learned to look to these papers for advertising information. Meaningless generalities are all too common in many of our country newspapers.

This condition has compelled many dealers to resort to broadside and circular advertising-direct-by-mail methods as the only means of securing results from advertising expenditures.

But if the retailer does not make his advertising copy descriptive and informative, he fails in his advertising. And these are two essential points to consider in writing advertising copy.

Millions of dollars are going from the retailers to the mail order houses, because the retail merchants in the smaller cities and towns are taking "too much for granted" and not playing up the merits and desirability of their own merchandise.

To prove to you that the average retailer does not write advertising copy as he should-I am going to tell you of a few instances that happened last year.

Up in Mankato, Minn., last year-the retail merchants decided to make a survey and discover if possible why so much business was going to the mail order houses. After some delay an organization was perfected, but a number of retailers were unenthusiastic and preferred to take the attitude that there was no use-that "mail order" prices were lower, and other excuses. But there was a minister there who was not so easily discouraged and who undertook to conduct the investigation. And what he uncovered was a revelation to the merchants of that city. 
In making as nearly as possible a house-to-house canvass, this gentleman entered a country home where a mattress had been purchased from a mail order house. Conversation with the housewife brought out the fact that from the catalog descriptions the family had been led to believe that it was a better mattress and lower priced than any that could have been purchased in the city.

Upon investigating this article in their own city, later, these people found that they could have purchased a much better mattress and at $\$ 1$ less.

In another instance a farmer had bought a mail order separator. The wife admitted that after an investigation they found they could have purchased a better cream separator at home for less money than they had paid the mail order houses.

Now, I am going to ask you this question: What is wrong? Is it the fault of the consumer? Not at all.

The fault was entirely with the local merchants who failed to describe their wares attractively and convincingly. Perhaps the retailers were not even advertising mattresses and cream separators.

And much of the responsibility for such situations lies with the newspaper publisher, for it is up to you gentlemen to encourage more and better advertising on the part of the merchants.

I am firmly convinced that newspaper publishers should insist that advertising copy be up to the highest standard. The newspaper publishers should realize that if a store is to expect results from advertising, copy must be attractively written, be descriptive and informative - and used only in connection with carefully planned advertisements.

As mentioned before-the merchant takes "too much for granted." He operates under the impression that every customer knows the comparative quality of the merchandise and will come into his store after it.

Not long ago a prominent retailer came to my department for information and assistance for a "Loom-End Sale." We prepared a lay-out, together with an editorial and several suggested headings. When a copy of the advertisement was sent us as printed the merchant had included a very satisfactory variety of merchandise-and the display was excellent. But up in the right hand corner, within a bold rule box, was this statement: "PERCALES-Lights and Darks, per yard 19c."

Not a bad statement as far as price was concerned-but it was the startling lack of real information. Here was a dealer who had visited the wholesale market-spent many hours in buying the merchandise-and then described it in such an unsatisfactory manner.

Such descriptions do not mean anything. They do not carry any information to the imagination of the housewife who may need or desire some particular pattern. The merchant should have given more information regarding colors, checks, stripes, etc., and not attempted the announcement of the entire shipment of percales with so little description. Women want specific information before they visit a store-especially if they have to travel many miles to make their purchases, and it makes a lot of difference whether advertising copy contains adequate information, or not.

Bear in mind, editors, that this class of copy must compete with mail order catalogs, wherein much of the piece goods is illustrated in colors-with descriptions explicit and carefully written. 
It is well that the newspaper publisher, and the retailer, realize that the rural trade now. receives the daily newspapers from larger cities, with all the enticing advertisements; that these same rural residents get the popular magazines carrying many mail order advertisements of the larger general concerns, as well as many of the ready-to-wear specialty lines.

I might suggest that it would be wise for the country merchant to prepare his own advertising much along these same lines. Such copy writing need not be left to the merchant alone, but he should be assisted by the employees or heads of the various departments.

There are a few exceptions, where retail advertising copy is as carefully prepared as that of the mail order concerns-but the instances are rare. This is why so many rural people imagine mail order prices are so extraordinarily low. They are sold on the value and apparent merit of the merchandise through the well written descriptions long before they come to the price.

Your own advertising copy and general lay-outs for the retailers should be prepared well in advance-the same as is done in the large department stores. And the copy should be given an adequate amount of space.

Advertising copy should be written up in sections upon separate sheets of paper-instead of being hurriedly scribbled upon a yard or two of wrapping paper. Then you will have a good looking, well-displayed, well-balanced advertisement.

How our retailers expect a printer to fold and unfold a large piece of wrapping paper a dozen or more times in the process of setting an advertisement is beyond my understanding. Yet these haphazard methods continueand the printer is as much to blame as the merchant.

Advertising, as taught here in the university, emphasizes the importance of lay-outs, writing interesting, descriptive copy and proper display.

I might also mention the fact that the retail advertising field offers wonderful opportunities for women. Years ago it was a rare thing to find a young woman in the advertising department of many of our larger department stores -now they are the chief copy writers for the large department stores. They are naturally adapted to this class of work-they instinctively know merchandise and can write better copy, much better, than the average man.

There was some mention this morning about retailers picking some few specials and advertising them in a limited space. This may be all right where price is a paramount issue, but you will find that it will pay much better for the average retailer to use larger space in the weekly paper, and advertise a larger variety of merchandise. The greater the variety, the more extended and varied the appeal.

\section{As an illustration:}

If I were to advertise hosiery to my trade-wouldn't it be better if, instead of selecting one item of hosiery, I chose at least two items of women's hose-one a cheap grade and one a higher grade; then at least two items in men's hose-and perhaps an item or two for children?

And the same rule holds good in many other lines. 


\title{
Advertising a City
}

\author{
By G. V. Kenton \\ Editor, St. Louis News Service
}

The idea of advertising a community or city, contrary to the first thought of most of us, has been in existence since man came to inhabit the earth. But the first advertising was not with printer's ink, as we have it in this modern age, the ancient message having been carried by word of mouth.

Thus in Bible times we have Moses advertising to the children of Israel the land flowing with milk and honey, to which he was to lead them. Or in the early days of American history we may recall how the first intrepid trappers and frontiersmen crossed the Alleghenies and carried back word of the fertile valleys and wonderful hunting territory in Kentucky and Ohio. Their simple narratives about this new and unexplored region brought new faces and later a steady flow of settlers.

But the plan of advertising a city through the medium of newspapers, trade journals and magazines is comparatively new. St. Louis, being one of the pioneers in this rapidly developing field, has long since had the watchful eyes of other municipalities turned toward her.

Five years ago, when St. Louis launched its first campaign to attract new citizens and industries, municipal advertising was in the experimental stage. Today its worth has been so conclusively demonstrated that almost every city or hamlet that is alert and progressive is taking an inventory of its assets and advertising them to the world.

Municipalities, like business firms, have had the truth brought home to them that advertising does pay. No business, great or small, depending upon public support, can be run with highest success - unless it be backwardwithout advertising. You know you can run a locomotive without steam, but it would have to be going down hill.

Some states, realizing the value of publicity and advertising, have passed laws authorizing cities to appropriate sums for advertising purposes. Colorado has made such a provision. Florida has imposed a mill tax, and twenty counties are making use of the fund it creates. Not one has had an inclination to drop the plan. The recent surge of visitors to Miami may be attributed to advertising. Last year that city spent $\$ 146,000$ to tell of its enticing climate, bathing beaches, hotels and other attractions. Not to be outdone, California, on the other seaboard, has been preaching from the mountain top, of its balmy skies, endless sunshine, and tropical wonders. This year a campaign is under way in Los Angeles to raise $\$ 1,000,000$ to spread abroad the message that tourists, citizens and new industries are still welcome in the "land of eternal sunshine."

In the meantime, St. Louis, with a studied effort to be conservative and avoid the spectacular, has been consistently broadcasting the message that it is the logical trade center, being located near the middle of the United States and in the midst of a region where raw materials and agricultural products are to be had in abundance; that its varied industries, excellent schools, churches, parks, railroad and other transportation facilities make it a good place in which to live, work and play.

At the outset of the St. Louis campaign an effort was made to bring in factories in sixteen lines of industry needed to round out the city as a well- 
balanced industrial center. Since that time fifty-one industries in ten of these lines have been obtained directly or indirectly as a result of advertising. Many others came through the efforts of the Industrial Department of the Chamber of Commerce, several of which were traceable to inquiries growing out of the advertising campaign.

As a result of the coming of these industries, thousands of additional workmen have become citizens of St. Louis and the wealth of the metropolis has been increased. Besides gaining in population wealth and commerce, a spirit of progress has been awakened by the advertising, which has developed a type of citizenship that responds to community undertakings and works in harmony for.the common good. Citizens generally are coming to understand that the added prosperity enjoyed through municipal advertising is shared directly or indirectly by all.

In the 1924 program 26 magazines of national circulation and 127 newspapers, principally in the trade zone lying to the South and the Southwest, were used to convey the message of St. Louis. That these paid advertisements have elicited world-wide interest is attested by the fact that letters by the hundred pour into the Chamber of Commerce asking for further information about the city. To these writers are mailed booklets setting forth salient facts, and communication is continued with those who evince further interest.

A noteworthy feature of the advertising campaign for the past year has been the establishment of the St. Louis News Service, a bureau organized by the Municipal Advertising Committee to disseminate constructive news of St. Louis and its citizens. This bureau supplies 273 newspapers in the United States, Canada, and Mexico with a twice-a-week service on news events or feature articles, which press association wires have not had time to carry. In addition 103 Missouri papers are being supplied with an All-Missouri service, which gives a brief review of constructive news in different sections of the state.

It is the aim of the news bureau, of which I am the editor, to work in harmony with press association wires and not to duplicate in any way the material they are sending out. There has been perfect cooperation along this line in St. Louis and the press associations are glad to get aid on worth-while stories.

In a city of $1,000,000$ inhabitants it is manifest that a great many good stories, especially those that can be built along feature lines, go to waste. They are to be had on every hand, merely for the asking or through a little creative effort. This is the task of the news bureau, as I see it - to dig up these features, put them into shape for the editor and mail them out. Crime news, unless it be constructive, is not handled.

Considerable attention is being paid by the news bureau to trade journals and magazines, which seem eager to receive articles that tell of special activities and novel events. These usually are accompanied by good, clear photographs of an 8 ,by 10 size. Some of the magazines that recently have accepted articles are: Sportsmen's: Digest, Cincinnati; Ohio, on the: "State Park System"; Public Educator, Boston; "The St: Louis Educational Museum"; Southern Architect" and Building News, Atlanta, Ga., "St. Louis School Building Program"; Oral Hygiene, Boston, "Oral Hygiene in St. Louis Schools"; Glenn Group Headwear Publications, New York, "Hat Industry in St. Louis"; Market Grower's Journal, Louisville, Ky., "How St. Louis Solves Truck Growers' Problems." 
Photographs are used not only by the magazines but by newspapers as well as in their rotogravure sections and on their daily picture pages. Most editors are glad to get well-taken photos of subjects that have a news value or are freakish enough to amuse. Nearly 200 pictures have been sent out by the news bureau and many more will be released shortly.

As a third activity, the bureau editor aids frequently in arranging for motion pictures of St. Louis scenes and events. The film corporations keep staff men at their call in the city, and pictures they take are used frequently in the weekly news reels of their respective companies. Co-operation with these men affords a city a splendid opportunity to show some of its attractions to the outside world.

I believe that St. Louis stands unique among the large cities in the establishment of a news bureau. There are other organizations in large cities following much the same program as the St. Louis service but they usually are conducted by the Chamber of Commerce. The St. Louis bureau is sponsored by the City of St. Louis, the Chamber of Commerce, and the Advertising Club, and has an office separate from any of these organizations. No political influence is wielded over the bureau or the advertising campaign, although the city government through the Board of Aldermen each year appropriates one-half of the amount spent for advertising. In the past year there was a fund of $\$ 70,000$, one-half appropriated by the city and half by business and professional men. In previous years the total annual amount was $\$ 50,000$. Business men have been quick to see the advantage of the enterprise and willingly subscribe their share.

Since the inauguration of the news bureau on December 15 last, it has mailed out 50,000 pages of copy representing about 12,000,000 words. From clippings in hand, it is estimated about 900 columns have been printed about St. Louis and her citizens. And the expense has not been great, as all articles are sent by mail. The results have been so convincing that other cities have begun to ask about our plan and have begun to use it.

In conduct of the new bureau, I am trying to be of real service to other editors. I had much experience with publicity men in my many years of editorship on The St. Louis Star and know that they are very useful when their energies are bent in the right direction. Too many editors have been imposed upon by unprincipled publicity men who hesitate to stick to facts.

But in municipal advertising we must deal with the truth, for what is more forceful than truth and facts? We must be able to back up our statements when the visitor arrives to see our city. We must be able to show him everything we have described in our advertising and then some.

Honest, sincere effort to tell the world of your city's advantages does pay. Every penny spent wisely brings back a nickel with it. St. Louis has found it so and that's why a spirit of optimism is pervading the air while the noise of building is heard on every hand, that's why she is facing the future with the brightest prospects of her career; and that's why leaders from other municipalities are coming to the Mound City to learn of our Municipal Opera, our fashion show, our zoo, our schools and our $\$ 87,000,000$ bond issue. 


\section{The New Profession-Public Relations}

\section{By Frank LeRoy Blanchard \\ Director of Public Relations, Henry L. Doherty E Company, New York}

As human beings we are so constituted that we want to be thought well of by our friends and neighbors. The man who says he does not care what people think of him is not telling the truth. He may be indifferent to the attitude of his enemies, or those whom he dislikes, but there are others, few or many, as the case may be, whose good will he desires and to gain which he will exert every effort.

The old proverb: "A good name is rather to be chosen than great riches, and loving favor than silver and gold," is just as true today as when Solomon wrote it thousands of years ago. The testimony of the ages is to the effect that wealth obtained through criminal acts or the disregard of the rights of others stains indelibly the name of him who holds it.

This craving for the good opinion of our fellows, if not an inherited characteristic, was early acquired by our remote ancestors as the result of their observations and experiences. Much of our happiness and no small degree of the success which we attain through the exercise of our mental faculties depend upon the degree to which we can command it.

What is true of the individual is also true of groups of individuals brought together for a common purpose as represented by a firm, company, association or corporation. They take on the dominating characteristics of the persons composing them. Hence, we find them ambitious to win great commercial success, jealous of their reputations and proud of their accomplishments. Such organizations, if intelligently directed, do not, except in rare cases, defy public opinion, but, rather, strive to win its favor through service, as a sound business policy. The larger they are and the more numerous their points of contact with the public, the greater their need of its good will and support. These they cannot have unless they have established a reputation for fair dealing in the conduct of their business. In other words, they must deserve the confidence of the public before they can expect to win it.

It is not possible for me to discuss with you, at this time, all of the methods employed in the promotion of favorable public relations. I purpose, however, to outline the more important, and especially those employed by the large industrial, financial and commercial corporations.

What do we mean by public relations? The term, while self-explanatory, may be defined as the relations existing between the company, on the one hand, and the people whom it serves, on the other. If the company through the conduct of its affairs gains their approval: if it shows a live interest in, and contributes to the upbuilding of the community: if, as in the case of public utilities, it is a monopoly, and does not take advantage of its position to unduly increase its revenues at the expense of its customers, and constantly strives to improve its service or product, it is quite evident it will have the good will not only of its customers, but also of the rank and file of the residents of the community or localities in which it is doing business. The better these relations are, the greater its chances for achieving a financial success.

Because of the realization, on the part of important commercial organizations, of the desirability of establishing favorable public relations, and 
the recognition of the fact that special attention must be given to the promotion of good will, a new profession has developed which has already made a place for itself in the business world. Its practitioners are experts in the use of methods that have been devised to promote a better knowledge and appreciation of the companies they are engaged in exploiting, and the merchandise or service they are marketing. The employment of advertising managers, agents, and, in some cases, of publicity or press representatives, by such corporations is not a new feature in business practice. In fact, they have been engaged in handling their advertising for at least forty years, and in promoting their publicity for a quarter of a century or more. But with the passage of time and the amazing expansion of commercial operations there has come an insistent demand for a different type of advertising and publicity executives.

The advertising manager of one of these large corporations must be more than a writer of clever advertising messages and the possessor of a knowledge of the best mediums. He should have had actual sales experience and know the art of merchandising and marketing; he must thoroughly understand the characteristics and buying habits of the people to whom his advertisements are addressed; he must possess executive ability in order to properly direct the work of his staff, sometimes numbering forty or fifty persons; he must have an agreeable personality and be able to win and keep the confidence and respect of the officers or other executives of his company.

The old-time press agent finds no place in the better class of business organizations today. He has been superseded by the better educated and more dependable writer who has won his spurs as a star reporter on a newspaper, or as a contributor to the popular magazines. It is not his mission to invent stories to exploit his employers or their business, but to dig out real news and facts concerning the organization and so present them in written form that the editors of newspapers and periodicals will be glad to print them on account of their inherent value. He analyzes markets and financial statements and breathes the breath of life into commercial data which under his skillful pen, teem with popular interest. He makes friends readily and possesses initiative and vision.

Because of the rapid increase in the size and importance of industrial, public utility and financial corporations, greater and still greater demands are being made upon the advertising and publicity departments of these organizations. Whereas, formerly a staff of half a dozen or even fewer persons was employed, now it is not unusual for big manufacturing companies to have 250 on the public relations department payroll.

In order to secure economic efficiency and unity of effort all of the several groups of persons engaged in the preparation of the various kinds of adver-
tising matter, in the editing and publishing of house organs, and in rendering special personal service, are brought together in a single department, often, though not always, known as the department of public relations, and presided over by a widely experienced executive.

Such a department ranks among the most important departments of a manufacturing or public utility corporation because upon the character of the service it renders depends, in a large measure, not only the successful marketing of its goods, but the promotion of good will among its customers, its employes and the general public. It is the voice of the company. The sales and the public relations departments are the chief points of contact between the company and the outside business world. While, in a sense, both are con- 
ducted independently, yet it is only through the closest co-operation between them that the policies and plans of the organization can best be carried to fulfillment.

The director of such a department must be a man of unusual ability and experience. He must be an advertising expert-one who is recognized as an authority on its various phases. He must be a first-class journalist, for he must know what kind of news and publicity matter the newspapers and trade publications will print and the form in which it is most acceptable. Editorial experience is absolutely essential in supervising the issue of the company's publications. He must be a good organizer, possess the knack of winning the loyalty and active co-operation of the members of his staff and be able to originate ways and means for creating favorable public opinion.

He must be a diplomat, because he will be called upon to adjust differences that may arise between his company and the newspapers, or the public. $\mathrm{He}$ must forestall or endeavor to defeat proposed local, state or national legislation that is inimical to its interests, and promote such measures as will enhance them.

As he will be invited to address chambers of commerce, advertising and other clubs, public meetings, and educational and other institutions, he should be a good public speaker.

You can readily perceive from what $I$ have said that the man who possesses these qualifications is not easily found because the combination is exceptional. To have been engaged in newspaper work long enough to acquire a practical knowledge of editorial technique, and in the advertising profession sufficient time to master its intricacies, warrants the conclusion that the director of public relations must be over 30 years of age, assuming, of course, that he was 21 when he completed his college or university course. To acquire a knowledge of the different branches of the work is not a matter of a few weeks or months of study, but of years.

It follows, therefore, that the person who is selected for the important position of director of public relations is of ten nearer 40 years of age than 30 because of the many kinds of experience he must have had before assuming its duties.

The chief functions of a public relations department, as we have already seen, are: 1-The preparation and placing of the company's advertising; 2-Editing and publishing its house organs; 3-Furnishing news and special articles to daily newspapers, trade publications, and magazines; 4-The practice of diplomacy.

The organization of the advertising section is about the same as that of an advertising agency, except that there are no account executives or salesmen. In the large manufacturing companies the manager has under his direction a staff of copy writers, artists, printers, production, research and trade investigation men.

The publication section enlists the services of editors and writers, the number depending, of course, upon the number and size of the house organs issued. The Westinghouse Company, of East Pittsburgh, has a staff of thirtyfive. The work is carried on under the direction of an editor-in-chief and a managing editor. Each publication, especially in the technical field, has its own 
taff, the reason being that the expert knowledge of the subject to which it is devoted is such that few editors are competent to write on topics belonging to another field than their own.

The news section personnel is composed of experienced newspaper men whose training has especially fitted them for the work they have in hand. If the corporation organization is a large one, they have an abundance of data upon which to draw for publication in the magazines and newspapers. The writers must be thoroughly familiar with the policies and trade practices of the company. They must be accurate in every statement they make, for only in this way can they gain the confidence of the editors of those periodicals to which their contributions are sent.

The diplomatic function is usually exercised by the director of the public relations department or by his chief assistant.

The plan of organization I have outlined was adopted at my suggestion by Henry L. Doherty \& Company, when the Department of Public Relations, of which I became director, was established early in 1922. Henry L. Doherty \& Company are the fiscal agents and operating managers of Cities Service Company, a holding company, composed of over 100 subsidiary companies, 64 of which are gas and electric light and power companies, the others being mostly oil producing, refining and marketing organizations. The gross earnings of the Cities Service Company and its subsidiaries last year were $\$ 117,207,691.84$.

The Public Relations Department prepares advertisements for newspapers and business publications in New York and all employe and customer ownership campaigns conducted in the cities of twenty-six states where we own properties.

The department does not furnish local copy for these operating companies for the reason that it is obviously impossible for any writer at headquarters to know local conditions and the peculiarities of a hundred cities well enough to prepare copy that is best adapted to each one. Therefore, the advertisements are written by hometown talent under the direction of the general managers of the several companies, the Public Relations Department in New York acting only in an advisory capacity. Except in a few instances all other advertising matter originates at headquarters.

In addition to the 100 subsidiary companies we have six teen district offices, located in the larger cities of the country, for the sale of Cities Service securities. All of the advertisements inserted by the managers in the local newspapers are prepared in New York. Our total investment in advertising last year was $\$ 450,000$.

In a large organization like ours, the furnishing of news of its subsidiaries to the various publications, next to the preparation of advertising, is the most important activity of the Public Relations Department. You rightly conclude that in an organization composed of so many public utility and other companies, and operating in so many different states, considerable news of an interesting character originates. We are constantly enlarging our plants and installing new equipment; extending the service lines of our railways, electric light, gas and power companies; bringing in new natural gas and oil wells; purchasing additional properties; making changes in the management of local public utilities and in troducing improvements in their service.

All of these activities are of in terest to the local public because the utility company is always one of the most important business enterprises of the city in which it is established. Those that concern the larger companies are also of 
interest to investors, brokers and bankers in such financial centers as New York, Chicago, San Francisco, Philadelphia, New Orleans, Boston and other leading cities of the country.

The news is collected by our correspondents and forwarded by mail or telegraph to the Department of Public Relations, New York, where it is condensed or rewritten to meet the requirements of the newspapers and the trade press. The items are then sent to the editors or press associations by messenger, mail, or telegraph, as the nature of the news demands. It is through publicity of this kind and through direct advertising that good will and a favorable attitude of mind on the part of the public is created. The better informed people become upon the affairs of your company, the character of its securities, and the advantages of your service or product, providing, of course, its worth has been tested, and found worthy of public confidence, the greater will be the measure of its prosperity.

Some idea of the scope of my personal activities as director of the Doherty Public Relations Department may be had from the fact that last year, in addition to supervising the work of my staff at headquarters, I attended nine conventions and seventeen committee meetings of business and advertising associations, delivered twenty-seven addresses and traveled 26,964 miles.

While I have been able during the brief time assigned to this address, as part of a program pregnant with human interest, to do no more than outline some of the outstanding features of a public relations department, I hope you have obtained a clear idea as to its importance as a recent development in business management or practice. If you wish to secure more knowledge upon the subject, I suggest that you read the following books: "Winning the Public" by S. M. Kennedy, vice-president of the Southern California Edison Company, and "Public Relations" by John C. Long. The latter is published by the McGraw-Hill Book Company.

This, then, is the new profession to which some of the ambitious journalists and advertising practitioners are already directing their attention. To those who have the patience and perseverance to equip themselves for the position it offers adequate compensation-greater, in fact, than it is possible to receive in journalism or in the advertising field except in a comparatively few cases.

While today those engaged in public relations management are small in number, the future is rich in possibilities. Some of the large public utility companies that now have public relations departments are $\mathrm{H}$. M. Byllesby \& Company, Middle West Utilities Company, Southern California Edison Company, Edison Electric Illuminating Company, Empire Gas \& Fuel Company, Pacific Gas \& Electric Company and the American Water Works \& Electric Company. It is inevitable that within the next fifteen or twenty years every large corporation engaged in a business that depends for its income upon the patronage of many people will find it necessary to establish a public relations department. The grouping of a number of public utility companies under a centralized management which is now going on in different parts of the United States will make possible the employment of a considerable number of highly trained executives as directors.

The road the candidate for public relations honors must travel may be long and beset with difficulties, but he who has a natural aptitude for the work and the courage to master the problems he encounters, will, in the end, become an accredited practitioner in this new and highly influential profession. 